\title{
Correlation Between Soy Milk Formula Consumption with Plasma Estradiol Level and Growth of Children in Denpasar
}

\author{
I Gusti Ayu Trisna Windiani ${ }^{1}{ }^{*}$, Alice Indradjaja ${ }^{2}$, I Gusti Agung Ngurah Sugitha Adnyana ${ }^{1}$, \\ Soetjiningsih ${ }^{1}$
}

${ }^{1}$ Department of Child Health, Udayana University Medical School/Sanglah Hospital, Denpasar, Indonesia

${ }^{2}$ Bengkayang Hospital, Bengkayang, Indonesia

\section{Email address:}

trisnawindianidr@yahoo.co.id (I G. A. T. Windiani), aliceindradjaja82@gmail.com (A. Indradjaja), sugad168@yahoo.com (I G. A. N. S.Adnyana),prof_soetji@yahoo.com (Soetjiningsih)

${ }^{*}$ Corresponding author

\section{To cite this article:}

I Gusti Ayu Trisna Windiani, Alice Indradjaja, I Gusti Agung Ngurah Sugitha Adnyana, Soetjiningsih. Correlation Between Soy Milk Formula Consumption with Plasma Estradiol Level and Growth of Children in Denpasar. American Journal of Pediatrics. Vol. 5, No. 4, 2019, pp. 286-290. doi: 10.11648/j.ajp.20190504.31

Received: November 6, 2019; Accepted: December 16, 2019; Published: December 24, 2019

\begin{abstract}
Soy milk formula is a formula which contains soybean as a substitute for cow's milk protein. Consumption of soy formula has caused widespread concern especially related to the effect of isoflavones. We aimed to determine the correlation of plasma estradiol level and to compare physical growth in children who consumed soy milk formula with children who consumed cow's milk formula. This was a case-control study of children aged six months to two years old who were treated at pediatric outpatient clinic in Sanglah Hospital and private pediatric outpatient clinic in Denpasar from April to July 2015. Subjects were divided into children who consumed soy milk formula and children who consumed cow's milk formula. Data regarding physical examination, anthropometric measurements, diet types and estradiol level were obtained. Total 28 subjects enrolled. We found significant difference in estradiol level between the two groups (OR: $0.33 ; \mathrm{p}=0.001 ; 95 \% \mathrm{CI}=0.17-$ 0.64). We found no significant difference in sexual development between those two groups (OR: $1.25 ; \mathrm{p}=0.12 ; 95 \% \mathrm{CI}=0.92$ - 1.71). Furthermore we found no significantly different in physical growth of subjects who consumed soy milk formula compared to cow's milk formula ( $\mathrm{p}>0.05$ ). Soy milk formula consumption did not associated with significant difference of sexual development and growth in children consuming soy milk compared to cow's milk. However, it related to increament of estradiol level.
\end{abstract}

Keywords: Soy Milk Formula, Estradiol Levels, Growth

\section{Introduction}

Soy milk formula is a special formula which contains soybean as a substitution for cow's milk protein [1]. Several indications for the usage of soy milk formula in infants and children include cow's milk allergy, galactosemia, vegetarian diet and various digestive problems such as lactose intolerance [2].

Soy protein contains isoflavones which has estrogenic activity known as phytoestrogens. Some concerns about soy formula are associated with isoflavones, which can bind to estrogen receptors and have structure and hormonal effect that resemble endogenous hormones $17 \beta$-estradiol [3]. There is a concern that phytoestrogens in soy formula will mimic or alter estradiol metabolism and modifies process affected by estradiol [4-7]. Some research also stated that soy milk contains lower protein than cow's milk and phytate which can damage important ions such as zinc and reduce essential micronutrient absorption from the gastrointestinal tract [8]

Vegetarian diet is not a new issue in Denpasar. The number of vegetarians in Bali, especially in Gianyar regency, is reported to be as much as $60 \%$ from the entire population [9]. Consumption of soy milk formula is an temporary alternative for parents who choose vegetarian diet for children.

Research of the effect from soy milk formula consumption on children's growth is still controversial. In addition, 
research on the effect of isoflavones has not been carried out systematically while the vegetarian population in Denpasar is quite large. The effect of long-term soy milk formula consumption has caused widespread concern, therefore we conducted a study aimed to evaluate the correlation of soy milk consumption with plasma estradiol level and growth of children in Denpasar.

\section{Materials and Methods}

This was a case-control study of children aged six months to two years old who were treated at pediatric outpatient clinic in Sanglah Hospital and a private pediatric outpatient clinic in Denpasar from April to July 2015. Cases were vegetarian children who consumed soy milk formula with or without breast milk for at least 6 months. The control group consisted of subjects who consumed cow's milk formula with or without breast milk. Samples were collected consecutivel while the selection of control subjects was done randomly based on age and sex from the case group. The exclusion criteria were as follows: (1) children who consume both formula milk and soy milk, (2) on hormonal therapy, (3) suffer thyroid hormone abnormalities, (4) receive corticosteroid therapy, (5) suffer from major congenital abnormalities, chromosomal abnormalities and tumors, (6) experience liver and kidney function disorders, (7) suffer from chronic diseases, such as asthma, nephrotic syndrome and leukemia.

The parents were given complete information and asked their willingness to take part in this study and signed informed consent. Data were collected through questionnaire which contained information regarding complete identification of parents and patients, objective data on the condition of the patient, diagnosis when the patient was admitted to hospital, anthropometric measurements, types of diet consumed by subjects and estradiol level in plasma. The physical examination including anthropometric measurements and laboratory examination were completed and carried out by the researcher and assisted by residents in Growth and Development sub-section.

All data entries were made and analyzed by computer programs (SPSS 17.0 for windows). Descriptive analysis was used to determine the characteristics of samples, which were presented in the form of frequency distribution, cross tabulation, percentage, middle value, minimum and maximum value. The differences of characteristic data between case and control groups were analyzed by using Chi-square statistical tests for nominal scale or KolmogorovSmirnov test as the alternative. Statistical analysis of estradiol levels was carried out by using Chi-square or alternatively using Fisher exact test. Odds ratio precision was expressed by $95 \%$ confidence interval. P value of $<0.05$ was considered statistically significant.

\section{Results}

Total 28 subjects enrolled in this study. Among 28 respondents, 15 children $(54 \%)$ were male, four of them (27\%) consumed soy milk formula. The characteristics of respondents are shown in Table 1.

Among 28 respondents, 9 children (32\%) consumed breast milk which was interspersed with soy milk formula. Types of diet in in those subjects are shown in Table 2.

Table 1. Characteristics of research subjects.

\begin{tabular}{lll}
\hline & Soy milk formula & Cow's milk formula \\
\hline $\begin{array}{l}\text { Gender } \\
\text { Male, } \mathrm{n}(\%)\end{array}$ & $4(27)$ & $11(73)$ \\
Female, $\mathrm{n}(\%)$ & $5(38)$ & $8(61)$ \\
$\begin{array}{l}\text { Gestational age (weeks) } \\
\text { Nutrition intake, n (\%) }\end{array}$ & 38 & 38 \\
$>100 \%$ RDA & & $8(100)$ \\
$80-100 \%$ RDA & 0 & $10(59)$ \\
$<80 \%$ RDA & $7(41)$ & 0 \\
$\begin{array}{l}\text { Intake of soy protein, n (\%) } \\
<50 \%\end{array}$ & $1(100)$ & 0 \\
$\geq 50 \%$ & $2(22)$ & 0 \\
$\begin{array}{l}\text { Mother's education levels, n (\%) } \\
\text { Primary school graduate }\end{array}$ & $7(78)$ & $1(50)$ \\
Junior high school graduate & $1(16.7)$ & $5(83.3)$ \\
$\begin{array}{l}\text { Senior high school graduate } \\
\text { University graduate }\end{array}$ & $1(14)$ & $6(86)$ \\
Mother's occupation, $\mathrm{n}(\%)$ & $5(45)$ & $6(55)$ \\
Unemployed (housewife) & $5(38)$ & $8(62)$ \\
Employed & $3(23)$ & $10(77)$ \\
$\begin{array}{l}\text { Family income, n (\%) } \\
<1.800 .000,- \text { per month }\end{array}$ & 0 & $1(100)$ \\
$\geq 1.800 .000,-$ per month & $8(32)$ & $17(68)$ \\
\hline
\end{tabular}

Table 2. Types of diet in research subjects.

\begin{tabular}{ll}
\hline Diet & N (\%) \\
\hline BM and soy milk formula & $10(36)$ \\
BM and cow's milk formula & $18(64)$ \\
\hline
\end{tabular}

$\mathrm{BM}=$ breast milk

Estradiol level in respondents were tested with Fisher's exact test. There was a significant difference between the group of children who consumed soy milk formula and children who consumed cow's milk formula with OR: $0.33 ; \mathrm{p}$ $=0.001 ; 95 \% \mathrm{CI}=0.17-0.64$. This can be seen in Table 3 .

Table 3. Estradiol levels in children consuming soy milk formula and cow's milk formula.

\begin{tabular}{llllll}
\hline & Soy milk formula & Cow milk formula & P & OR \\
\hline Estradiol $<7 \mathrm{pg} / \mathrm{mL}$ & 0 & 12 & $05 \%$ CI & 0.001 & 0.33 \\
Estradiol $\geq 7 \mathrm{pg} / \mathrm{mL}$ & 10 & 6 & $0.17-0.64$ \\
\hline
\end{tabular}

CI $95 \%=$ confidence interval 95\%; $\mathrm{p}=$ probability

The effects of soy milk formula consumption in children's sexual development compared to cow's milk formula was 
tested by using Fisher's exact test. There was no significant difference in the sexual development of children between those two groups with OR: $1.25 ; \mathrm{p}=0.12 ; 95 \% \mathrm{CI}=0.92-$ 1.71. Pubertal status of subjects can be seen in Table 4 .

Table 4. Status of puberty in children consuming soy formula and cow's formula.

\begin{tabular}{llllll}
\hline & Soy formula & Cow milk formula & P & OR & 95\% CI \\
\hline Normal & 8 & 18 & 0.12 & \multirow{2}{*}{$0.92-1.71$} \\
Precocious puberty & 2 & 0 & 0.92 & \\
\hline
\end{tabular}

CI $95 \%=$ confidence interval 95\%; $\mathrm{p}=$ probability

The effect of soy milk formula consumption in children's growth compared to cow's milk formula was tested with Kolmogorov-Smirnov test which showed no significant difference ( $p>0.05)$. Growth of children who consumed soy milk formula and cow's milk formula are displayed in Table 5.

Table 5. Growth of children consuming soy milk formula and cow's milk formula.

\begin{tabular}{|c|c|c|c|}
\hline & Soy milk formula & Cow's milk formula & $\mathbf{P}$ \\
\hline \multicolumn{4}{|l|}{$\mathrm{BW} / \mathrm{A}$} \\
\hline Normal, n (\%) & $7(88)$ & $14(88)$ & \multirow{3}{*}{0.947} \\
\hline Underweight, n (\%) & $1(12)$ & 0 & \\
\hline Severely underweight, n (\%) & 0 & $2(12)$ & \\
\hline \multicolumn{4}{|l|}{$\mathrm{BL} / \mathrm{A}$} \\
\hline Very tall, n (\%) & 0 & $2(11)$ & \multirow{3}{*}{0.372} \\
\hline Normal, n (\%) & $8(100)$ & $11(61)$ & \\
\hline Severly Stunted, n (\%) & 0 & $2(11)$ & \\
\hline \multicolumn{4}{|l|}{$\mathrm{BW} / \mathrm{BL}$} \\
\hline Obesity, n (\%) & $1(6)$ & 0 & \multirow{5}{*}{0.996} \\
\hline Overweight, n (\%) & $1(6)$ & 0 & \\
\hline Normal, n (\%) & $15(82)$ & $8(100)$ & \\
\hline Wasted, n (\%) & 0 & 0 & \\
\hline Severely wasted, n (\%) & $1(6)$ & 0 & \\
\hline Obesity, n (\%) & $1(6)$ & 0 & \multirow{5}{*}{0.786} \\
\hline Overweight, n (\%) & $1(6)$ & 0 & \\
\hline Normal, n (\%) & $15(82)$ & $8(100)$ & \\
\hline Wasted, n (\%) & 0 & 0 & \\
\hline Severely wasted, n (\%) & $1(6)$ & 0 & \\
\hline
\end{tabular}

\section{Discussion}

Soy formula is formula milk made from soybeans that has been fortified and given to children to substitute breast milk, provides additional nutrients or as alternative to cow's milk protein [10]. Soy protein contains isoflavones which has estrogenic activity known as phytoestrogen. Phytoestrogen is a component of natural plants which possesses biological activity that resemble estrogen [11]. Estradiol is the most active form of estrogen [12]. One concern related to the consumption of soy milk formula is associated with exposure of phytoestrogens in soy formula that may mimic or alter estradiol metabolism and modifies process affected by estradiol [4-7]. This study showed a significant difference in estradiol levels between children who consumed soy milk formula and children who consumed cow's milk formula (OR: $0.33 ; \mathrm{p}=0.001 ; 95 \% \mathrm{CI}=0.17-0.64$ ).

Sex hormones are crucial to achieve normal reproductive development and function. Soy milk formula contains isoflavones which have estrogen-like action, so there is a concern that consuming soy milk formula will impact the development of reproductive system [10]. This study found no significant difference in the sexual development of children who consumed soy milk formula and cow's milk formula (OR: $1.25 ; \mathrm{p}=0.12 ; 95 \% \mathrm{CI}=0.92-1.71)$. This finding is consistent with a cross-sectional study conducted by Berbaum et al., whom evaluated the estrogenic effects of soy formula on child's sexual development. Higher sexual maturity was obtained in infants (ages $3-6$ months) who received soy milk formula compared to those who received breast milk or cow's milk formula but was not statistically significant $(p=0.07)$ [13]. The results of a prospective study conducted by Gilchrist et al., in infants aged 2-3 months to 6 years old indicated that there was no relation between the given diet (breast milk, cow's milk formula, and soy milk formula) and size of reproductive organs that were evaluated at 4 months of age by using ultrasound [11].

Results of this study revealed that soy milk formula consumption did not correlate with difference in growth of children. It was found that body weight/age, body length/age, body weight/body length and BMI/age showed no significant difference between subjects who consumed soy milk formula and cow's milk formula. Some research have been carried out on humans to evaluate the effect of soy milk formula on growth which also did not show difference of growth in children who consumed soy milk formula [14-21]. This finding is also in accordance with a study by Zeiger et al., on the growth of children consuming soy milk formula 
compared to cow's milk formula at the age of one month to four months old in Lowa University which showed that there was no difference in growth between those two groups [8]. A study by Lasekan et al., also reported that the administration of soy milk formula in infants in the first year showed no difference in growth compared to infants who received breast milk followed by formula milk made from cow's milk protein [22]. In contrast, Kohler et al whom reported that children who consumed soy formula had lower body weight until the sixth week and lower bone mineralization up to 3 months of age compared to the group that consumed cow's milk protein and breast milk, but this difference was not meaningful after being re-evaluated within 6 months [18].

There are some possibilities which researcher considered as the constraints of this study which are small number of respondents, the setting of study which took place at pediatric outpatient clinic in Sanglah Hospital which is a tertiary health care center where patients mostly suffer from chronic diseases or other diseases which met exclusion criteria and the reluctance of parents regarding blood sampling procedure.

\section{Conclusion}

We conclude that soy milk formula consumption is not significant associated with difference in sexual development and growth in children compared to cow's milk. It is, however related to increased levels of estradiol. Soy protein may be used as formula milk to meet the nutritional needs of children to achieve normal growth especially in children with special condition. Further investigation with larger and more diverse subjects is needed to achieve better understanding regarding the effect of soy milk formula consumption.

\section{Funding}

The authors received no financial support for the research, authorship, and/or publication of this article.

\section{References}

[1] Ruhrah J. The soy bean in infant feeding: preliminary report. Arch Pediatr 1909; 26: 496-501.

[2] American Academy of Pediatrics Committe on Nutrition. Soy protein-based formulas: recommendations for use in infant feeding. Pediatrics 1998; 101: 148-53.

[3] Munro IC, Harwood M, Hlywka JJ, Stephen AM, Doull J, Flamm WG, et al. Soy isoflavones: a safety review. Nutr Rev 2003; 61: 1-33.

[4] Setchell KD. Soy isoflavones-benefit and risks from nature's selection estrogen receptor modulators (SERMs). J Am Coll Nutr 2001; 20: 354-62.

[5] Katherine MF, Sherry AF, K. Barry D, Retha RN. Effects of genistein exposure on sexually dimorphic behaviors in rats. Toxicol Sci 2000; 55: 311-9.
[6] Richard WL, Nigel B, Gillian MM, Anthony S, Susan S, Michael H, et al. The effects of the phytoestrogen genistein on the postnatal development of rat. Toxicol Sci 2003; 71: 74-83.

[7] Karen ALT, Marion W, Keith M, Irene G, J Ian M, Richard MS. Infant feeding with soy formula milk: effects on puberty progression, reproductive function and testicullar cell numbers in marmoset monkey in adulthood. Hum Reprod 2006; 4: 896904.

[8] Zeiger RS, Sampson HA, Bock SA, Burcks AW Jr, Harden K, Noone S, et al. Soy allergy in infants and children with IgEassociated cow's milk allergy. J Pediatr 1999; 134: 614-22.

[9] Nai HME, Adhi KT, Sutiari NK. Kecukupan asupan gizi remaja vegetarian dan nonvegetarian di yayasan Sri Sathya Sai Bali tahun 2011. IJPH 2012; 1: 43-9.

[10] NTP. NTP multigenerational reproductive study of genistein (cas no. 446-72-0) in sprague-dawley rats (feed study). Natl Toxicol Program Tech Rep Ser 2008; 539: 1-266.

[11] Gilchrist JM, Moore MB, Andres A, Estroff JA, Badger TM. Ultrasonographic patterns of reproductive organs in infants fed soy formula: comparisons to infants fed breast milk and milk formula. J Pediatr 2009; 156 (2): 215-20.

[12] Speroff L, Glass RH, Case NG. Abnormal puberty and growth problems. In: Seiffer DB, Speroff L, editors. Clinical endocrinology gynecology and infertility. $6^{\text {th }}$ edition. Philadephia: Williams \& Wilkins; 1999. p. 381-419.

[13] Bernbaum JC, Umbach DM, Ragan NB, Ballard JL, Archer JI, Schmidt-Davis H, dkk. Pilot studies of estrogen-related physical findings in infants. Environ Health Perspect 2008; 116: 416-20.

[14] Chan GM, Leeper L, Book LS. Effects of soy formulas on mineral metabolism in term infants. Am J Dis Child 1987; 141: 527-30.

[15] Hillman LS. Bone mineral content in term infants fed human milk, cow milk-based formula, or soy-based formula. J Pediatr 1988; 113: 208-12.

[16] Hillman LS, Chow W, Salmons SS, Weaver E, Erickson M, Hansen J. Vitamin D metabolism, mineral homeostasis, and bone mineralization in term infants fed human milk, cow milk-based formula, or soy-based formula. J Pediatr 1988; 112: 864-74.

[17] Jung AL, Carr SL. A soy protein formula and a milk-based formula-a comparative evaluation in milk-tolerant infants showed no significant nutritional differences. Clin Pediatr 1977; 16: 982-5.

[18] Köhler L, Meeuwisse G, Mortensson W. Food intake and growth of infants between six and twenty-six weeks of age on breast milk, cow's milk formula, or soy formula. Acta Paediatr Scand 1984; 73: 40-8.

[19] Mimouni F, Campaigne B, Neylan M, Tsang RC. Bone mineralization in the first year of life in infants fed human milk, cow-milk formula, or soy-based formula. J Pediatr 1993; 122: 348-54.

[20] Sellars WA, Halpern SR, Johnson RB, Anderson DW, Jr, Saperstein S, Shannon BS, Jr. New growth charts: soy, cow, and breast milk comparison. Ann Allergy 1971; 29: 126-34. 
[21] Steichen JJ, Tsang RC. Bone mineralization and growth in term infants fed soy-based or cow milk-based formula. J Pediatr 1987; 110: 687-92.
[22] Lasekan JB, Ostrom KM, Jacobs JR, Blatter MM, Ndife LI, Gooch WM 3rd, et al. Growth of newborn, term infants fed soy formulas for 1 year. Clin Pediatr 1999; 38: 563-71. 